\title{
Documents related to the Caucasus during the Second World War in the archive of the Polish Institute and Sikorski Museum in London*
}

Zarys treści: Artykuł prezentuje dokumenty przechowywane w Instytucie Polskim i Muzeum im. gen. Sikorskiego w Londynie dotyczące Kaukazu w czasach II wojny światowej. Materiał ten niewątpliwie zainteresuje badaczy zajmujących się dziejami Armii Polskiej w ZSRR. Nasuwa się wniosek, że Kaukaz dla polskich polityków był etapem przejściowym w procesie przechodzenia wojska polskiego spod dowództwa sowieckiego pod brytyjskie.

Outline of content: The article presents documents from the Polish Institute and Sikorski Museum in London about the Caucasus during the Second World War. The presented material can be of interest to those exploring the history of the Polish Army in the USSR. It can be concluded that the Caucasus in the minds of Polish policymakers was to be a transitional stage in the process of bringing Polish troops out of the Soviet command and under the command of the British.

Słowa kluczowe: Kaukaz, Polska, II wojna światowa, Armia Polska, Winston Churchill, Władysław Sikorski, rząd polski na uchodźstwie

Keywords: Caucasus, Poland, World War II, Polish Army, Winston Churchill, Władysław Sikorski, Polish government-in-exile

The archive of the Polish Institute and Sikorski Museum at 20 Prince's Gate, London, is one of three Polish archives in London; the other two are at the Józef Piłsudski Institute and the Polish Underground Movement Study Trust. The Institute, originally called the General Sikorski Historical Institute, was established in May 1945. To avoid pressure from the British government and the communist Polish government, it received charity status instead of being an institute of the

* This article was written thanks to the scholarship received by the author from The De Brzezie Lanckoronski Foundation. 
Polish government-in-exile. ${ }^{1}$ The main objective of the Institute was to preserve Polish records, many of which relate to the Polish Armed Forces in the West.

The Institute's archive contains more than a kilometre of documents that mainly relate to the Second World War and Poland's participation in it. The records related to the Presidency of the Council of Ministers constitute one of the biggest collections. Several relate to the Caucasus and most of those are present in this text. It was intended to assist Second World War researchers and those who study Polish plans related to the withdrawal of the Polish Army from the central part of the Soviet Union, since the Caucasian issue was usually raised in exactly this context.

One document in the archive relates to the period when the Soviet Union cooperated with Germany. Soviet aggression against Poland and Finland and the continuous economic cooperation between the USSR (The Union of Soviet Socialist Republics) and Germany led top British military leaders to prepare plans to destroy the Soviet oil industry in the Caucasus with the aim of paralysing the economy of both countries. These British projects were presented in detail by Patrick R. Osborn in his book Operation Pike: Britain versus the Soviet Union, 1939-1941, published in 2000. The document related to this issue is kept in the records of the Presidency of the Council of Ministers with reference number PRM.II.11.6. This is a copy of a report marked as "secret" by Władysław Günther, a Polish envoy in Athens. Dated 28 February 1940, the report describes the situation in Albania and possible military action in the Caucasus. The report was sent to the Ministry of Foreign Affairs and reached Angers, ${ }^{2}$ where the seat of the Polish government-in-exile was then located. It was considered so significant that on 8 March it was transferred to the PM, Władysław Sikorski. ${ }^{3}$

The report described a meeting between Günther and Ali Serry Omar-bey, an Egyptian envoy in Athens, who was appointed as the Secretary General of the Ministry of Foreign Affairs in Cairo. According to Omar-bey, Turkey would probably occupy Baku with the allied fleet before the summer, to reduce the export of Soviet oil to Germany. Omar-bey also highlighted the following facts:

- Egypt had become a huge British arsenal.

- In official and private talks during his last visit to Egypt, General Weygand ${ }^{4}$ had explained the necessity of creating a southeast allied front.

1 Historia, http://www.pism.co.uk/historia.htm (accessed: 26 July 2015).

2 Angers is a town in western France where there was a seat of the Polish government-in-exile from November 1939 to June 1940, headed by Gen. Władysław Sikorski as Prime Minister. It was also the residence of the President, Władysław Raczkiewicz.

3 Władysław Sikorski was appointed as Prime Minister on 30 September 1939 by President Władysław Raczkiewicz.

4 This concerns the French Gen. Maxime Weygand, who in August 1939 was appointed as commander-in-chief for the Orient Theatre of Operation, i.e. the commander of the French forces in the Middle East. 
- During the previous big war, Turkey took Sarikamish, ${ }^{5}$ so to speak, on its own. At that time, the occupation of Baku by Turkey with the allied fleet and air forces did not pose any problems, especially as the Soviet fleet in the Black Sea was not strong, even for a single allied fleet operating in the east part of the Mediterranean Basin.

- Since the goal of the Turkish and allied military expedition against the Soviet Union was the Soviet oil fields, it was probable that they would also try to gain a bigger influence over the Romanian oil. Therefore, it could be assumed that the actions in the Caucasus and Constanța would take place simultaneously ${ }^{6}$ in order to also threaten the Soviet Union and Germany with warfare in Romania.

Władysław Günther summed up part of his report on the Caucasus by saying that Omar-bey's statements mainly reflected the plans of the British who operated in the Mediterranean Basin and Southeast Europe.

The main group of documents in which the issue of the Caucasus is raised consists of materials related to the plans of moving Polish military units formed in the Orenburg Province ${ }^{7}$ to the south. When the Soviet Union attacked Poland on 17 September 1939, any diplomatic contacts between those countries were broken. They were renewed because of British mediation that took place after German aggression against the Soviet Union. As a result, on 30 July 1941 Poland and the USSR reached an agreement between that was signed by Poland's PM, Gen. Sikorski and the ambassador of the Soviet Union in London, Ivan Maisky. Article 4 states that the government of the USSR agreed to form a Polish Army in the USSR.

In the first half of August, the command over the Polish Army in the Soviet Union was given by the Polish government to Gen. Władysław Anders, held in Lubyanka prison. Because the agreement of 30 July 1941 provided amnesty for Polish citizens held as prisoners in the Soviet Union, those who were already in Soviet forced-labour camps, prisons, and other places of exile joined the army. However, the cooperation between Poland and the Soviet Union did not go well. Polish institutions were worried that they had not received any news from Polish officers kept by the Soviet government in the camps in Kozelsk, Starobelsk and Ostashkov. The Soviet Union consequently refused to answer any questions about the missing people and impeded the search. ${ }^{8}$ Furthermore, the Soviet amnesty did not include all Polish citizens, some of whom were sent to settle in Central

${ }^{5}$ Sarikamish is a city in northeast Turkey. It was occupied by Turkey during the war with Armenia in 1920, and after the official end of the First World War.

${ }^{6}$ Constanta is the largest trade port in Romania.

7 The Polish Army under the command of Gen. W. Anders was formed in the region of Buzuluk in Orenburg Province, where its headquarters and staff were situated in 1941-1942.

8 Polish military captives kept in the camps in Kozelsk, Starobelsk and Ostashkov were shot without trial by the Political Bureau of the Central Committee of the CPSU (b) on 5 March 1940. This action is part of a wider crime known in historiography as the Katyn massacre, which relates to the murder of at least 21 thousand Polish citizens by the Soviet authorities. 
Asia, while others were forcibly moved to Soviet work groups. Another serious obstacle in the cooperation was the fact that the Soviet government recognised only ethnic Poles as Polish citizens and did not allow other Polish citizens (on 1 September 1939) to go to the area where the Polish Army was being formed. Another disputable issue was the fact that the Soviet government initially agreed that the Polish Army should have only 30 thousand soldiers, whereas Poland wanted many more (some circles in the Polish government planned to form an army of 200 thousand soldiers in the Soviet Union). These difficulties were behind the plan to withdraw the Polish Army from Soviet command and place it under British command. This issue was directly related to moving Polish military units in the Soviet Union closer to British troops. The Caucasus was considered a practical region to which Polish military units could be moved.

In the archive of the Polish Institute and Sikorski Museum, in the records of the Presidency of the Council of Ministers with reference number PRM 42.1.21, is a copy of a telegram on the deployment of the Polish army in the Caucasus. It was drawn up in English, probably because the information included in the telegram was intended for the British. The document dated 26 September 1941 was marked as "secret". It was written by Poland's PM, Gen. Władysław Sikorski, and the addressee was Gen. Zygmunt Bohusz-Szyszko, ${ }^{9}$ staying then in Moscow.

At the beginning of the telegram, Sikorski recommended that Bohusz-Szyszko discuss with Gen. Sir Hastings Ismay ${ }^{10}$ two issues significant for Poles, related to forming a Polish Army in the Soviet Union. Outlining the situation, Poland's PM pointed out that, due to the rapid southward German drive on the east front towards Donbas and the Caucasus, the protection of Caucasian oil fields had become the most urgent issue. Therefore, Bohusz-Szyszko told Ismay that Sikorski wanted the Polish armed forces to defend them. At the same time, he emphasised the Polish government was not responsible for the delay in their preparation and equipment. Furthermore, in the telegram Poland's PM mentioned that he did not suggest that the Soviet government move the Polish forces to the Caucasus because he wanted to avoid suspicion. Therefore, Bohusz-Szyszko should ask Ismay to propose that the Soviet government move the Polish troops to the Caucasus immediately. Furthermore, Poland's PM wanted the British impact to speed up the equipment transport from Arkhangelsk to the Polish forces to equip and arm them properly in order to make them useful to both the Soviet Union and the Allies.

The reply to the telegram by Sikorski is in the records of the Presidency of the Council of Ministers, with reference number PRM 41.3.22. This is a copy of the telegram in Polish, but no transmission date is shown.

\footnotetext{
9 After the signing of the Sikorski-Maisky agreement, Zygmunt Bohusz-Szyszko headed the Polish military mission in the USSR.

10 Before the war, Hastings Lionel Ismay was the Secretary of the Committee of Imperial Defense. When Winston Churchill took over as Prime Minister, he appointed H. Ismay as his chief military assistant and staff officer. In 1952-1957, he was the first general secretary of NATO.
} 
The author of the telegram requested that Gen. Sikorski be informed about the reply from Gen. Noel Mason-MacFarlane in Moscow ${ }^{11}$ to the question by Poland's PM to Gen. Ismay on 26 September. MacFarlane informed the Polish that he had discussed the telegram from Sikorski with Gen. Ismay and the British ambassador. ${ }^{12}$ He promised he would do his best to help send the equipment more quickly from Arkhangelsk to the Polish troops. In addition, he informed the Polish representatives that for three weeks he had been putting pressure on the Soviet headquarters to allow him to send a liaison officer to the headquarters of Gen. Anders; however, he had not yet been given consent. As for the second issue, MacFarlane stated that any initiative to move the Polish troops from the Volga region to the Caucasus could be undertaken only by the representatives of the Polish government in Moscow. He emphasised that he had no objections so that Poles, when talking to Russians, could say that the British generally thought that Polish demands on the deployment of Polish units were justified.

An interesting document can be found in the records of the Presidency of the Council of Ministers, with reference number PRM 39B.20. This is a report on the talks between PM Sikorski, Minister Edward Raczyński, ${ }^{13}$ and PM Winston Churchill and his secretary. Among other things, it raised the issue of Polish troops in the Caucasus. These talks took place on 24 October 1941: the same date as on the report. It was written on Polish Embassy paper in London and marked as "top secret". The author of the document is Raczyński who, as he pointed out himself, intentionally took into account mainly Churchill's arguments.

The beginning of the document indicates that the talks took place over breakfast. They stemmed from a question from Churchill to Gen. Sikorski about whether he still intended to visit Russia, as a trip there was potentially dangerous. According to Churchill, this visit would benefit Poland and the Allies; however, Gen. Sikorski was too valuable to be exposed unnecessarily. Therefore, the British PM asked the Polish general to reconsider his visit carefully. Sikorski replied that he felt compelled because of his sense of duty to the soldiers he wanted to visit in Tobruk, ${ }^{14}$ and to the 2 million Polish refugees in the Soviet Union.

Churchill replied that he did not claim any right to interfere in this decision, and that he understood Sikorski's motives. The British PM was interested in the

${ }_{11}$ In 1941-1942, Noel Mason-MacFarlane was Head of the British Military Mission in Moscow.

12 Stafford Cripps was at that time the UK Ambassador in Moscow.

13 Bernard Edward Raczyński was a Polish diplomat. From 1932, he represented Poland at the League of Nations and, from 1934, he was the Polish ambassador in London. He held this last position until July 1945, when the British government withdrew recognition of the government of the Republic of Poland in exile. In 1941-1943, E. Raczyński was also the Foreign Minister. After the war, he remained in exile and engaged, among others, in political activities. In 19791986, E. Raczyński was the President of Poland in exile. He died in London in 1993.

14 Tobruk is a city in northeast Libya. During the Second World War, it was the site of prolonged fighting between German-Italian troops and Allied forces, including the Polish Independent Carpathian Brigade, commanded by General Stanisław Kopański. 
route and the preparations that had been made. He added that, because the Soviet government opposed the formation of a larger Polish Army, they could not be trusted to release all the prisoners or those held in camps. Instead, they sent volunteers who wanted to join the Polish troops to work; therefore, an insufficient number were sent to the Polish military camps. ${ }^{15}$

General Sikorski described the situation related to the formation of the Polish Army in the Soviet Union and confirmed that he needed to go there because of the Soviet disloyalty. He said that the visit had been planned in a way that it could be terminated in Tobruk if it became apparent that it was impossible to rely on the good will of the Soviet government. However, he added that the last telegram from the Polish ambassador in Moscow indicated that due to the arrival of the PM the implementation of the agreement would be possible, ${ }^{16}$ which would be very significant for Poland. To describe the whole situation better, Raczyński showed Churchill a telegram received from Ambassador Stanisław Kot $^{17}$ in Kuybyshev ${ }^{18}$ that summarised his talks with Vyacheslav Molotov. The Soviet minister of foreign affairs gave assurance that imprisoned Polish citizens would be released and pardoned due to the "arrival of the general". In the telegram, Ambassador Kot also pointed out the unwilling position of the Soviet government on the formation of a Polish Army bigger than two divisions.

Those present at this meeting agreed that Soviet resistance had been stronger and more effective since the beginning of the war with Germany than had been optimistically assumed; however, they admitted that the situation on the front was very difficult for the Soviet Union. Churchill, based on recently obtained infor-

15 The Sikorski-Maisky agreement provided an amnesty for Polish citizens imprisoned in NKVD prisons and Gulag concentration camps. However, the creation of the Polish army in the USSR was carried out based on the Polish-Soviet agreement signed in August 1941. The Soviet side agreed that the Polish forces could contain 30 thousand soldiers. At the same time, there was a dispute about the definition of "Polish citizen". Polish committees admitted Polish citizens to the army people on September 1, 1939, while the Soviet authorities believed that this should apply only to persons of "Polish nationality", and only such persons should be exempted from the camps, which was a violation of the Sikorski-Maisky agreement. Another significant divergence was the fact that although the Polish army in the USSR was equipped by the US and UK as part of the Lend-Lease agreement, the Soviet authorities refused to agree to an increase in the number, despite a steady stream of volunteers.

16 The Polish-Soviet agreement to establish the Polish army on the Soviet territory was signed on 14 August 1941.

17 Stanisław Kot was a historian and professor at Jagiellonian University in Kraków. In September 1939, he was in exile and became the Deputy Prime Minister in the government of Gen. Władysław Sikorski. In 1941-1942, he was the ambassador of the Polish government-in-exile in the Soviet Union. After the end of World War II, he remained in exile and died in Great Britain in 1975.

18 After signing the Sikorski-Maisky agreement in 1941 the Polish embassy in Moscow was re-opened. However, in the same year the diplomatic corps and Soviet Government were evacuated to Kuybyshev. 
mation, assessed the likelihood of successfully defending of Moscow to be 50 per cent, which was slightly higher than a few days previously. He then expressed his view that until recently the clash between the two armies on the very long front had been so fierce that had fully engaged all the forces on both sides; therefore, the German forces could not be used elsewhere for special purposes. The British PM noticed that the situation had already changed and not all the German forces were engaged, which made them more dangerous.

In the next part of the talks, Gen. Sikorski discussed the status of the military operations and paid special attention to the fact that the Soviets did not have a plan for coordinating the movements of individual armies.

During the talks, Churchill informed Sikorski about the situation in Iran, in particular Soviet demands to the UK. According to the British PM, despite the difficult situation on their own main front, the Soviet government still had an occupying army in Iran that consisted of five divisions, the presence of which was causing unrest among local people due to its deep unpopularity. As a result, three British divisions, which in different circumstances could have been used against Germans, had to maintain order in Iran and protect the inhabitants against the activities of the Soviet occupying forces. Churchill stated that the railway connecting the Persian Gulf to the Caspian Sea, which was one of the most important routes used by the Allies to fulfil Soviet needs, was already heavily exploited for the needs of the British forces deployed in Iran. Meanwhile, the Soviet Union demanded that the British divisions ${ }^{19}$ in that area take over one of the sections of the Soviet-German front. According to the British PM, this demand, for example at the Volga, would burden the only line of communication even more, thereby reducing its usefulness for the Soviet Union.

The British told the Poles that the optimum solution would mean moving five Soviet divisions from Iran to the Caucasus in order to improve the defence of this important region, which was then defended by only four Soviet divisions. In their opinion, this would quickly calm the situation in Iran, thereby relieving the British military forces. For Poland, the position of its partners was important since, for the UK, an accumulation of as many Polish troops as possible in the south (the document specified that the best solution for the British was deployment in Iran) would, through British efforts in winter, allow them to be completely armed, equipped and prepared for military actions in spring. Alternatively, if the Soviets had opposed this plan, the Polish troops would have been concentrated on the north coast of the Caspian Sea (the note says they would have been deployed near Astrakhan), to where the British could send the needed supplies. A footnote was added to this sentence, stating that PM Churchill explained that the British would possess the necessary weapons, as only machine guns were in short supply.

19 The suggestion about three divisions appeared in the note. 
This document indicated that PM Churchill knew that the Soviet government was against both British requests: they did not want to withdraw from Iran even if they lost Moscow and exposed their southern front to a threat. At the same time, they were afraid of larger Polish forces being formed and concentrated in the south, as they might form strategic alliances with the British Army.

Churchill suggested that Gen. Sikorski should appeal to Stalin and Molotov to be allowed to deploy the Polish troops to the south. In exchange, he should propose a call to the British government to support the Soviet demand for the UK to take over a section of the Soviet-German front. This statement included a footnote that Churchill implied that he expected support for the British proposal to move the Soviet divisions from Iran to defend the Caucasus.

Edward Raczyński wrote in the note that Churchill clearly pointed out that he could not authorise Gen. Sikorski to conduct specific negotiations over the discussed issue: in his opinion, these negotiations would depend on the constantly changing situation. However, according to Churchill, Poland's PM could make the Soviet government understand that he had reasons to believe the UK would compensate them for the concession. In addition, the British PM stated that he would act through British diplomacy to support Sikorski's efforts. The speakers agreed that the issue was difficult but deserved their efforts. A footnote shows that Churchill hoped that at least three Polish divisions would reach the direct operational range of the British Army. The author explained that - considering the course of Churchill's thinking and keeping in mind his typical remarks - he was confirmed in his belief that despite the lack of trust and sympathies between the Soviet Union and the UK, the latter would not be able to resist Stalin's pressure, since Stalin demanded that British troops directly participate in the action against Germany on the east front. Raczyński also wrote that, considering these facts, Churchill would want even more to obtain equivalent Soviet benefits. The British PM clearly stated that if the Soviet authorities agreed to such compensation, then the UK would also be ready to increase its input.

The document shows that Gen. Sikorski took note of Churchill's suggestions, as they would be a valuable asset in talks with the Soviet government. At the same time, he postulated transporting more soldiers to complement the Polish corps in Scotland, ${ }^{20}$ as well as moving several thousand soldiers to complement the Polish forces in Egypt. ${ }^{21}$ As the note says, Churchill addressed both postulates very positively. He said he would be happy if the Polish forces in Egypt were increased

20 After the defeat of France in July 1940, nearly 30 thousand Polish soldiers were deployed in camps in Scotland. The Polish Corps was created at the end of September 1941.

21 The Polish Independent Carpathian Brigade was founded in Syria in early 1940. After the capitulation of France, the unit moved to Palestine. At the end of 1940, some Polish troops were sent to near Alexandria in Egypt, where they expanded the defensive positions. They were not directed to the frontline because Poland was not formally at war with Italy. 
by one division, and would approve complementing the Polish forces in the UK, as it would be very appropriate.

Raczyński noted that Churchill talked about the Soviet government with clearer reluctance, criticism and mistrust than previously. In addition, he did not hide his mistrust, claiming that it was mutual. The British PM mentioned Vernon Bartlett ${ }^{22}$ as one of his information sources on Russia. He stated that Bartlett, as an extreme left-winger, had been very pro-Soviet until recently; however, when he had returned from Russia, he clearly came to his senses and became highly critical of the Soviet Union. Raczyński shared his observation in the document that Churchill had also obtained materials that explained Soviet methods and reality from Ambassador Cripps. ${ }^{23} \mathrm{He}$ added that despite all this, the British government was still determined to offer as much material support as possible for the Soviet Union.

The note says that during the talks, Churchill promised to send telegram instructions to Minister Oliver Lyttelton ${ }^{24}$ on the welcoming ceremony of Gen. Sikorski in the Middle East, as well as to Gen. Claude Auchinleck ${ }^{25}$ and Gen. XX, ${ }^{26}$ who commanded in Iran. The British PM assured several times that he was most anxious about Gen. Sikorski's personal safety. If the conduct of the Soviet government were improper in any aspect, Churchill would be ready to draw firm conclusions from that.

Raczyński stated in his note that Gen. Sikorski raised the issue of Churchill's attitude to Gen. de Gaulle, in particular the angle of his speech, in which he discouraged the French living in their homeland from anti-Nazi resistance. The British PM explained that despite his reservations to Gen. de Gaulle, he had come to a satisfying agreement with him when they had talked recently. He also pointed out that he did not share de Gaulle's view on opposing anti-German resistance and considered it wrong. Churchill emphasised that violent German retaliation would be desirable, because it would isolate the occupied countries from the invader and interfere with cooperation between them.

At the end of the talks, Gen. Sikorski raised the issue of the demands related to the Polish Army in Scotland. The first issue discussed with Gen. Alan Brooke ${ }^{27}$

22 Charles Vernon Bartlett, 1894-1983, was an English journalist and politician who was a member of parliament from 1938 to 1950 .

23 Stafford Cripps was the ambassador of Great Britain in the USSR in 1940-1942. In 1939, he was expelled from the Labour Party because of his pro-communist views.

${ }^{24}$ Oliver Lyttelton was the Minister of State in the Middle East in 1941-1942.

25 Gen. Claude Auchinleck was the commander of British forces in the Middle East at this time.

26 This was probably Edward Quinan, who planned the invasion of Iran and was one of the main commanders of the British-Soviet forces that occupied the country in late August and early September 1941. In addition, in September 1941, a Persian and Iraqi Force was created with the structure of the British armed forces and E. Quinan took command over it. It is difficult to say why the name was written as XX in the document. Perhaps this is because E. Raczyński did not know, although it seems unlikely.

27 Allan Brooke was one of the closest collaborators of Winston Churchill. In 1941-1946, he was the head of the Imperial General Staff. 
was the conversion of some Polish corps to form a complete armoured division. ${ }^{28}$ The note says that Gen. A. Brooke accepted the requests, believing that in this case some of the corps should be moved to England, where there were suitable training grounds for armoured forces.

According to Raczyński, Churchill confirmed his very positive opinion on meeting the needs of the Polish Army and he highly praised their military assets. However, he pointed out that the needs of the British Army in the Middle East, and Soviet needs even more so, largely exhausted the capability to deliver the equipment. The British PM stated that several divisions were being formed, including a guard division; therefore, there would be no equipment. Churchill said that more would be done later, but an armoured brigade would be formed, not a Polish armoured division. ${ }^{29}$

On 27 and 28 October 1941, another talk took place between the Polish and British representatives on the transfer of the Polish Army formed in the Soviet Union to the south. The report on the talks was given reference number PRM 39B.22. Again, it was drawn up by Raczyński. On the first day, apart from the Polish minister of foreign affairs, PM Sikorski, Minister Anthony Eden, ${ }^{30}$ Undersecretary Strang, ${ }^{31}$ and Retinger ${ }^{32}$ took part in the talks. However, on the second day Raczyński talked to Eden and Strang. A note on the meetings marked as "secret" was drawn up on Polish Embassy paper in London on 29 October 1941.

The first talks took place over breakfast, to which General Sikorski invited Eden and Strang. It mainly concerned the Polish postulates to the Soviet Union, in particular the difficulties caused by the Soviet government in forming the Polish Army. Taking advantage of this opportunity, Sikorski gave a memorandum that listed these postulates to Eden. ${ }^{33}$

The British minister explained to the Polish PM that since his talks with Churchill on 24 October, Soviet pressure on the direct participation of British forces in fighting against Germany had increased. He said that due to this and the worsening situation on the Russian front, the British government would probably be forced to immediately consent to involving the British Army on that front,

${ }^{28}$ The 1st Armoured Division was established in February 1942 with Gen. Stanisław Maczek as the commander.

29 This is a minor inaccuracy. At the time of the talks, a Polish armoured brigade was already part of the I Polish Corps: the 16th Armoured Brigade. It was created in September 1941 on the foundation of I Tank Regiment.

30 Anthony Eden was three times the Minister of Foreign Affairs of Great Britain, in 1936-1938, 1940-1945 and 1951-1955.

31 This probably relates to William Strang, a British diplomat and government adviser.

32 This most likely concerns Józef Retinger, W. Sikorski's advisor and probable British intelligence agent. After the war, he engaged in supporting European integration and improving Atlantic cooperation.

${ }^{33}$ In the presented documents, there is no mention of a memorandum, although there is in the attached note. 
without any demands for mutual benefits such as the evacuation of Soviet Army from Iran and the deployment of the Polish Army in Iran, or at least at its border. Eden declared that he was willing to call in Ambassador Ivan Maisky and request that the Polish postulates about the army be met.

Minister Raczyński raised a further postulate that was actually accepted by Minister Eden: if the British government accepted the Soviet demands (the note says that a decision was to be made that evening), it would allow the Polish government to use that against Moscow. Raczyński asked the British to inform Poland about their decision and to telegraph it to Ambassador Kot before they gave their answer to the Soviet government. It was agreed that both ministers would meet on that issue the next day, 28 October.

The note stated that Sikorski said he would make strong demands through Ambassador Kot on the Polish Army as well as on releasing ${ }^{34}$ and supplying civilians. If this did not change the Soviet position, he said he would terminate his trip in Egypt and not continue to the Soviet Union.

The information above ends the report by Raczyński on the talks on 27 October. The minister then described his meeting the next day with Eden and Strang, which took place at the Foreign Office. The British minister stated that before the meeting with the Polish diplomat he had met Ambassador Maisky, whom he had warned against "non-compliance with the Soviet Union's obligations to the Polish government". Eden says that Maisky did not deny he knew about the different views on the formation of a Polish Army. However, he argued, defending casuistically the position of his government, and denied that he had been unreliable in fulfilling his obligations. According to Maisky, there were no grounds for complaint regarding the Poles in the Soviet Union. At the request of Eden, the Soviet representative, Raczyński therefore agreed to submit a memorandum describing the current situation and inform him about the instructions sent to Ambassadors Kot and Jan Ciechanowski. ${ }^{35}$

The note says that Eden anonymously informed Raczyński about a new turn in the negotiations with the Soviet Union; however, at that stage the new agreement could not be used by the Polish government to support their postulates. This mainly related to the fact that Molotov described the British forces defending the Caucasus as undesired. According to the Soviet government, this would not provide a collective defence of the east front. Molotov insisted that the British forces should take an area further to the north (the note shows that he meant the area at the Volga). Eden stated that the British government considered these demands unreasonable because they were impossible to meet due to communication and equipment difficulties. He said that the British government still held the view

\footnotetext{
${ }^{34}$ This probably concerns the release of Poles detained in prisons and camps by the Soviet authorities.

35 Jan Ciechanowski was the Polish ambassador in Washington in 1941-1945.
} 
that the most reasonable plan was to withdraw five Soviet divisions from Iran, combine them with forces stationed in the Caucasus, and strengthen them with several British divisions and strong British air forces. A footnote contains Strang's comment that the Soviet government had serious reservations about the British being stationed in the Caucasus because at the end of the First World War they had shot Bolshevik commissars there. The Polish minister's report ends with Eden's information that the British government could not accept the Soviet demand on the involvement of their two or three divisions at the Volga.

When the Polish side realised that forming a Polish Army in the Soviet Union was increasingly difficult, they formulated a strategy to move it so it would in time be under British command. In this context, the Caucasus was considered a temporary place. This is proved by a document entitled "Przeniesienie Armii Polskiej w Rosji na Kaukaz. Propozycja, sposób realizacji i uzasadnienie" (Moving the Polish Army in Russia to the Caucasus. A proposal, implementation and justification), with reference number Kol.126.16. It was drawn up in Scotland in October 1941, signed by R.B.Z.S.

The document consists of twenty points divided into the following sections: "proposal", "implementation" and "justification". The proposal starts with a statement that it is essential to move the Polish Army in Russia from the provinces in central Volga, where it was formed, south to the Caucasus or the coast of the Caspian Sea. In another point, the main formal and technical difficulties are described. The formal reasons included the fact that the Polish Army in Russia was under the command of Soviets, who obviously were reluctant to do anything that could make Poles more independent. Therefore, the Soviet government would definitely treat moving the Polish forces south to the border of the Soviet territory near the British warships as an attempt to leave the Soviet command and join the British command. The technical difficulties included problems resulting from moving tens or hundreds of thousands of Poles (soldiers and families) a distance of one or two thousand kilometres, across a country without transport infrastructure and disrupted by warfare.

The document makes clear that circumstances at the time meant the Polish Army in Russia could not be moved to the Caucasus without considerable support from the British and possibly American governments, as the Polish government was helpless in this case. In this context, it was emphasised that the aim of the proposal was not to request regular British diplomatic support for possible Polish attempts to move the Polish military forces in Russia to the south. According to the author of the project, this could have been inappropriate for the British government for various reasons. However, a practical opportunity for the British to move the Polish Army from the central Volga to the Caucasus was noticed. The document shows that this opportunity existed due to an issue related to the Polish Army's equipment in Russia.

The section concerning the plan to transfer the Polish Army to the Caucasus contains a preliminary explanation that would be systematically presented by the 
Polish government. A new deployment was needed because, before joining the fight, the Polish Army in Russia had to obtain armament that would put it on a par with the best-armed German units. This position was primarily motivated by the fact that Poles were at that time the most reliable and best military anti-German units in southern Russia; therefore, they objectively deserved the best armament. Another argument was that Poles were often intentionally targeted by Germans in warfare. Thus, it was pointed out that if the Poles were insufficiently armed, there would be fear that Germans would intentionally concentrate their best-armed troops against them, which might result in the rapid destruction of the core of Polish forces in Russia, without any benefits for the Allies.

One point emphasised that the Polish Army in Russia should obtain the most modern American armament based on "Lease and lend", ${ }^{36}$ which Poland had obtained the right to before the Soviet Union entered the war. The author of the document concluded that the Polish Army had priority over the Soviet Army to the equipment from that source. In addition, the document shows that the type and quantity of American weapons delivered to the Polish Army would be agreed directly between the Polish and American governments, with the participation of the Soviet and British governments. The same point shows that negotiations on weapons transport to the Polish Army in Russia, the UK, and the Middle East were conducted jointly to ease the active role of the British government and the diplomatic presentation of this issue to the Soviet Union.

It was pointed out in the document that when a legal method and the amount and types of weapons were settled, only the issue of their transport to the Polish Army would remain. The author of the project took the view that mainly the Americans and British should decide on the weapons transport from the US to the east front. They could deliver weapons to the Polish Army in the Soviet Union by sea to the Persian Gulf, and from there across Iran to the Caucasus. When the equipment arrived in the Caucasus, only the Poles would collect it and supervise its delivery to the Soviet area. In the next point, it was suggested that to win some time, individual Polish Army units should be trained with the new equipment upon delivery and, if possible, near the routes used for transporting it in the Caucasus or nearby, for example at the Caspian Sea, near Astrakhan. If training new units with these weapons was necessary, the plan was to move Polish troops gradually to the Caucasus when the weapons were being delivered. This solution was suggested in case it was impossible to move the whole army at once, which, as was emphasised, seemed to be difficult due to political and technical reasons. It was pointed out that Polish civilians should also be moved to the south since they could not be left without governmental protection in the north and central provinces due to military factors.

36 The Lend-Lease Act was passed in March 1941. It gave power of attorney to the President of the United States to provide defence products to other governments. 
The document states that moving the Polish Army to the Caucasian province or the Caspian Sea, i.e. near the British Army, should take place no later than the spring of 1942, when the final German attack on Baku was expected. The author of the plan emphasised that the Polish Army in the Soviet Union under no circumstances could be deployed earlier on a different section of the front. He gave two arguments to support his opinion. The first concerned the armaments, on which Polish forces had to undergo proper training upon delivery. The second argument concerned the physical exhaustion of the Poles in the Soviet Union and that they should be fully recovered before deployment. It was emphasised that the Soviet government could not oppose such demands because its improper treatment of Polish prisoners and civilians had caused their poor physical condition. ${ }^{37}$ The next point indicated that in the final stage of warfare, the General British Command should take over the Polish Army in the Soviet Union and combine it with Gen. Archibald Wavell's ${ }^{38}$ army.

The third and last part of the project was entitled "General reasons" and consisted of five points. The first point argued that the concentration of the highly valuable and proven Polish Army near the Caucasus or even on the same Caucasian front would assist the British Army, as both were united by brotherhood in arms on many other fronts. It was emphasised that if the Caucasian oil fields were endangered by Germans in the spring of 1942, then such help for the British forced might be necessary. The next point shows that with such reliable allies in the Caucasus as the Poles, the British General Command would be able move some of their own sniper divisions more easily to the Libyan front to defeat the Italian Army finally, while not weakening the defence of the Caucasus and Iran.

The deployment of the Polish troops was also explained by their potentially significant military and political role. An issue was raised that on one hand the army could in some circumstances serve to support various non-Russian elements in the fight against Germany in the Soviet Union, specifically Ukrainians, Belarusians and Caucasians, who trusted Poles and could be hostile to Russians if Germany advanced further. It was also argued that the Polish Army would be a very unpopular opponent for the Romanian and Hungarian armies if they were sent by German general command to the Caucasian front, which seemed very likely. It was pointed out that Romanians and Hungarians, who fought fiercely against Russians, would fight poorly against Poles or would willingly surrender to protect themselves.

The penultimate point stated that if there were internal unrest in Soviet Russia, which the author of the project did not exclude completely, the Polish Army

37 It should be recalled that the Polish Army in the USSR was formed primarily from those released from Soviet camps under the Sikorski-Maisky agreement.

38 Gen. Archibald Wavell was a commander during World War II of British Army forces in the Middle East and Asia, and in 1943-1947 he was the Governor-General and Viceroy of India. 
in the Ural could find itself in a very difficult position and could even be of no use to the allies. He also raised an issue that it could be moved to the front too soon, which - taking into account the insufficient equipment and lack of support from the cooperating Soviet troops - might end in its complete destruction by Germans. ${ }^{39}$ Next, it was explained that in light of the recent events, the malice of the Soviet government should not be discounted, as it might want to destroy the only militarily strong Polish force in Eastern Europe, in order to have room for manoeuvre when the war ended.

The document ends with a statement that were the Germans to collapse and be driven back from the Caucasus, the Poles would concentrate in the Caucasus with the British Army and become a very important political factor. The author emphasised that this could make the "right" organisational development of Central Europe much easier after the war, since it is very easy to get there across the Black Sea from the Caucasus.

An interesting document can be found in the records of the Presidency of the Council of Ministers, with reference number PRM 44.2.21. This is a note drawn up by Ambassador Kot for PM Sikorski. Dated 22 November 1941, it was sent to the Polish diplomatic representation in Tehran and the Polish Ministry of Foreign Affairs in London. The contents of the telegram were marked as "secret" and related to withdrawing the Polish Army from the Soviet Union.

Ambassador Kot stated that Gen. MacFarlane had received a telegram from his Headquarters on the deployment of the Polish Army. In the telegram, the moving of the Polish troops to Iran was opposed due to communicational and food supply issues, as well as local political difficulties. On the other hand, the British General Headquarters suggested that the Polish troops should be moved to India in order to supply and rest them. The Polish diplomat informed the PM that the Soviet government might cause difficulties in letting all or some of the Polish soldiers go, or insist on their return to the Soviet Union when they were formed. He pointed out that MacFarlane was due to discuss the issue with Sikorski upon his arrival. Kot emphasised that this was top-secret information and Cripps had not received any orders.

In addition, the Polish diplomats in Iran participated in moving the Polish Army from central Russia to the south. In the records of the Presidency of the Council of Ministers with reference number PRM 44.1.16, there is a document

39 Polish analysts' concerns stemmed from the fact that the vast majority of Soviet military leaders did not count personal losses among their own troops. This had possible repercussions on Polish armed forces, for example in the case of the Polish 1st Tadeusz Kościuszko Infantry Division under the command of Gen. Zygmunt Berling, which for various reasons was not under the command of the Allies and the Polish Armed Forces in the West, but became a part of the Red Army. On the orders of Soviet leaders, on 12-13 October 1943 it fought the Wehrmacht near the village of Lenino in Belarus. The order to perform so-called "battle reconnaissance" and a lack of artillery support caused the division to lose $25 \%$ of total troops. 
entitled "W.P. na Kaukazie" (P.A. [Polish Army] in the Caucasus). This is a coded telegram sent on 29 November 1941 from the Polish diplomatic mission in Tehran to the Polish government-in-exile in London. The telegram, written by Jan KarszoSiedlewski, ${ }^{40}$ who was at that time an Extraordinary Member of Parliament and an authorised minister in Iran and Iraq, concerned a visit of the Polish PM, Gen. Sikorski, to the capital of Iran at the end of November 1941. The telegram related to the visit of the Polish PM to the Soviet Union, where he was to hold talks with Stalin on the formation of the Polish Army and the fate of Polish people, since many of them were held in Soviet forced-labour camps.

In the telegram, Karszo-Siedlewski stated that Ambassador Kot received full support of the $\mathrm{PM}^{41}$ for his position on displacing Poles from Uzbekistan. Next, he related that during his visit to Tehran the PM had experienced great kindness from all the English representatives. The diplomat said that they did not foresee any serious difficulties in evacuating the Polish troops from the Soviet Union across or to Iran and Iraq. However, as he pointed out in the document, the talks were only informative and any decisions would depend on agreement with Gen. Wavell. The author added that talks with an Iranian government representative proved that it would not be difficult for Poles to start Polish Red Cross ${ }^{42}$ activities in Iran. Apart from that, an issue related to an Iranian accredited legate to the Polish government was raised. According to Karszo-Siedlewski, the Shah was very sorry that PM Sikorski could not visit him due to lack of time; however, the Polish diplomat added that a meeting was scheduled on his way back from the Soviet Union, i.e. around 15 December.

In the next part of the telegram, the Polish MP related that Taray, the new Turkish ambassador, had met Sikorski and assured him that he was also accredited by the Polish government. He also assured the Polish PM that Turkey understood and supported his policy and the negotiations with the Soviet government. ${ }^{43}$ Karszo-Siedlewski said that the Turkish ambassador added that if Sikorski succeed

${ }^{40}$ Jan Karszo-Siedlewski was born in 1891 in Warsaw. He was a Polish diplomat who held posts in Belgrade, Prague, Moscow, Kiev, Tehran, Beirut, and others. He remained in exile after World War II and worked in the United States for the Committee for a Free Europe and the Library of Congress. He died in Washington in 1955.

41 Władysław Sikorski.

${ }^{42}$ Founded in 1919, the Polish Red Cross (Polski Czerwony Krzyż - PCK) is the oldest Polish humanitarian organization. During World War II, the organization dealt with, among others, helping Polish refugees. PCK activity in the area in the USSR where Polish troops were formed was extremely important to the Polish authorities due to the fact that there was a plan to transport tens of thousands of civilians with units.

43 The Sikorski-Maisky agreement was signed on 30 July 1941 between Poland and the Soviet Union. This restored relations between the states that had ceased on 17 September 1939 after the Soviet aggression on Poland. The agreement was signed by Gen. Władysław Sikorski, the Prime Minister of the Polish government in exile, and Ivan Maisky, the Soviet ambassador in Great Britain. 
in moving the Polish Army to Iraq and Iran to defend the Caucasus, then the entire Muslim world would be grateful to him for that. In addition, the Turkish diplomat said that Ambassador Michał Sokolnicki ${ }^{44}$ had a good reputation and the Turkish government had great trust in him.

The aforementioned documents are the main ones that concern the Caucasian issue in terms of moving the Polish military units formed in central Russia. There are few other materials relating to this region; however, one can be found under reference number PRM 102.2.40. The author of this document is unknown but he was probably an employee of the Polish Ministry of Foreign Affairs as the document was drawn up on Ministry paper and is dated London, 24 February 1943. The note was addressed to the Polish PM and marked as "secret". It is also marked as "Kuybyshev no. 107", which suggests that the issue discussed therein concerns the diplomatic corps visiting that city at that time. The author of the document informed Gen. Sikorski that information was circulating among members of diplomatic corps that in the Northern Caucasus, which had been retaken in recent weeks by the Soviet Army, supporters of axis powers among the Muslim population who cooperated with Germans during the occupation had been exterminated. The document ends with a statement that the percentage of those supporters was probably quite high.

The second document concerning the Caucasian inhabitants is in the records of the Presidency of the Council of Ministers, with reference number PRM 103.6.4. It was written by Col. Eunkiewicz ${ }^{45}$ from the Political Division of the Ministry of National Defence. The document was drawn up in London, dated 15 April 1943. It was sent to the Presidency of the Council of Ministers, the Ministry of Foreign Affairs, Ministry of Internal Affairs, and Ministry of Information and Documentation. This potentially advantageous information was sent to London by Łunkiewicz from Tehran. It related to the deteriorating Polish-Soviet relationship, which was feeding discontent among the Caucasian population in Tehran. For example, the document shows that members of the Musavat and Dashnaktsutyun thought that the Polish Army would be forced to fight a war against the Soviet Union and Caucasian inhabitants in Iran would help and support them in that war.

The documents related to the Caucasus in the Polish Institute and Sikorski Museum are interesting materials, mainly for people researching the history of the Polish Army formed in the Soviet Union. Based on analysis of these materials, it can be concluded that to Polish decision-makers, the Caucasus was to be a temporary

${ }^{44}$ Michał Sokolnicki was a Polish historian and diplomat who was appointed as Polish ambassador in Turkey in 1936. He left the post in September 1945, when the Turkish diplomatic recognition of the Polish government in exile was withdrawn. Sokolnicki, however, stayed in Turkey and became a lecturer at the University of Ankara. He died in 1967.

45 This probably relates to Col. Jerzy Łunkiewicz, who died in London in 1956. 
location for withdrawing Polish troops from Soviet command and possibly taking them under British command. In the war and political conditions at the end of 1941, the idea to deploy military units in the Caucasus seemed to be a reasonable move for Polish decision-makers. It was known that Germany's main aim on the south section of the front would be to occupy oil fields, in particular those in Chechnya and Azerbaijan. The Soviet defence was then not coordinated and it was impossible to predict the results of the German offensive in the Caucasus. The Polish command was considering defending this strategic region with Polish units. It was assumed that if the Polish Army were deployed on the front and near the area where the British troops operated, this would make supply transport easier, particularly for the Allies. When they reached proper battle readiness, the participation of the Polish troops in fighting on the east front would not support the argument often used by the Soviet government that the Polish commanders (mainly Gen. Anders) opposed the participation of the Polish Army in fighting on the east front. It was significant that the deployment of troops in the Caucasus would probably not stop the recruitment of soldiers to the units in the Soviet Union, since they were loyal to the Polish government in London. That happened later when all the Polish forces were evacuated to Iran.

For many reasons, the idea of moving the Polish Army to the Caucasus was never implemented. From a Soviet perspective, this was mainly a result of the fact that the government was afraid of deploying foreign units in that area because they could have made expansion plans more difficult, in particular the incorporation of Azerbaijan (the northern part of Iran). This issue was very important for Soviet decision-makers, as is proven by the information presented by Churchill that shows they were ready to sacrifice Moscow rather than evacuate their troops occupying Iran. In the Caucasus, where non-Russian people dominated, the deployment of the Polish forces near British forces was too risky for the Soviet government. In the military and political situation that developed in 1941, the Polish Army in the Caucasus could be too independent; therefore, supervision by the Soviets would be more difficult than if it were stationed in central Russia or the republics of Central Asia.

Moreover, the plans were not implemented because the Polish Army in the Soviet Union was then under the command of the Polish government in London, which had taken the view that Polish borders were inviolable before the German and Soviet aggression in September 1939. Thus, Soviet decision-makers did not feel they could rely on the Polish troops, which is proven by the documents presented here. It was assumed that the Polish Army in the Caucasus could greatly facilitate developing the proper organisation in Central Europe. In this case, the word "proper" did obviously not cover the Soviet plans.

The visit of Gen. Sikorski to Moscow on 3 December 1941 is discussed in some of the documents presented above. Subsequently, the Polish PM, Gen. Anders, and Ambassador Kot met in the Kremlin with Stalin, Molotov, and the Deputy 
Chief of the Red Army, Gen. Alexei Panfilov. ${ }^{46}$ Sikorski made strong demands that if the conditions for forming the Polish Army did not improve, it would be withdrawn. Probably affected by the situation on the front, Stalin agreed to make some concessions. As the German troops approached Moscow, he did not want to exacerbate the conflict with Poland because it might adversely affect his relationship with the UK. The Soviet government agreed to increase the number of soldiers in the Polish Army, whose headquarters were located in Yangiyo'l in the eastern part of Uzbekistan, to nearly a hundred thousand and move it to Central Asia. This operation took place in tragic conditions at the beginning of 1942, resulting in the death of several thousand people, mainly from typhus. Further difficulties arose from the crisis in the Soviet Union in the first half of 1942: the Polish Army did not receive the necessary armaments, equipment, and uniforms, and food rations were limited. The Soviet government repeatedly demanded to move the Polish units to the front, but Gen. Anders opposed this, as he thought that the troops were not yet ready to fight. However, he sought and obtained the agreement of the Soviet government on evacuating to Iran some soldiers for whom food rations were insufficient. More than forty thousand soldiers and civilians were transported at the end of March and beginning of April 1942 across Krasnovodsk ${ }^{47}$ to northern Iran. Gen. Anders intended to complete the evacuation of the Polish Army from the Soviet Union, which caused a conflict with PM, Gen. Sikorski, who at first opposed this solution. Finally, Gen. Anders' plans were carried out and, in July 1942, the Soviet government agreed to evacuate the Polish troops to Iran. This happened at the beginning of August and involved approx. seventy thousand soldiers and civilians. ${ }^{48}$ Thus, the army of Gen. Anders stayed in the Soviet Union under the Soviet command for a year before it was moved to Iran, where it was under British command. Subsequently, the Polish Armed Forces in the Soviet Union were combined with the Polish Army in the Middle East and a Polish Army in the East was formed. It must be pointed out that the evacuation of the Polish troops from the Soviet Union to Iran was fully compliant with the British plans of that time.

\footnotetext{
46 Alexei Panfilov was the Deputy Chief of the General Staff and the Head of the Main Intelligence Directorate of the General Staff of the Red Army. At the same time, he was plenipotentiary for the formation of the Polish Army in the USSR.

47 The present Turkmenbashi.

48 The creation of the Polish Army in the USSR and its derivation is specifically described by Wojciech Materski in the book Armia polska w ZSRR 1941-1942, Warsaw, 1992.
} 


\section{Bibliography}

Materski W., Armia polska w ZSRR 1941-1942, Warszawa, 1992.

Przemysław Adamczewski (b. 1981), Institute of Political Studies of the Polish Academy of Sciences (since 2016). He is a graduate of international relations at Adam Mickiewicz University in Poznań. In 2010 he was awarded PhD degree for the preparation of a thesis devoted to the Karabakh problem in the politics of Azerbaijan after 1991. In 2011 the thesis was awarded Prof. Robert Mrozewicz Prize for best doctoral dissertation on international relations and diplomacy. In 2011-2013 he was vice-chancellor of the Higher School of Humanities and Economics at Sieradz. In 2013-2015 was employed at Ivane Javakhishvili Institute of History and Ethnology in Tbilisi, where he worked on a research project "Mythologization of historical memory as a determinant of ethnic conflicts in the Caucasus" (adprzem@op.pl). 